\title{
From idealisation to demonisation and in- between: representations of American lawyers in legal FASP
}

Shaeda Isani

\section{(2) OpenEdition \\ Journals}

Electronic version

URL: http://journals.openedition.org/asp/782

DOI: $10.4000 /$ asp.782

ISBN: 978-2-8218-0400-5

ISSN: $2108-6354$

\section{Publisher}

Groupe d'étude et de recherche en anglais de spécialité

\section{Printed version}

Date of publication: 1 January 2005

Number of pages: $67-81$

ISSN: 1246-8185

\section{Electronic reference}

Shaeda Isani, « From idealisation to demonisation and in-between: representations of American lawyers in legal FASP », ASp [Online], 47-48 | 2005, Online since 16 February 2010, connection on 19 April 2019. URL : http://journals.openedition.org/asp/782 ; DOI : 10.4000/asp.782

This text was automatically generated on 19 April 2019.

Tous droits réservés 


\title{
From idealisation to demonisation and in-between: representations of American lawyers in legal FASP
}

\author{
Shaeda Isani
}

Since its identification as a genre in 1999 by Petit, FASP, or fiction à substrat professionnel, has generated substantial academic enquiry and publication. ${ }^{1}$ While Petit's founding article provides a comprehensive analysis of the genre's defining characteristics, for the purposes of this discussion, I shall simply draw attention to the core defining convention of the genre, the eponymous substrat professionnel or the highly specialised professional and/or technical springboard which fuels the plot dynamics of a fictional thriller. Much in the same vein, other terms proposed to define the genre have also focused on the author's exceptional degree of insider knowledge as, for example, "specialist literature" (Diaz-Santos 2000: 221-236) and "roman d'expert", the title of a French FASP collection.

2 The substrat professionnel being a source of constant diversification and regeneration, the FASP is a protean genre with multifarious ramifications. Some of the works and authors cited by Petit (1999) as "classic" representations of the genre are Tom Clancy's technomilitary thrillers, Michael Crichton's scientific thrillers, Robin Cook's medical thrillers and John Grisham's lawyer novels.

\section{Legal FASP. definition and taxonomy}

3 Interest in the law and law professionals is a constant to be found in classical and modern Western literature, as evidenced by the fact that authors as diverse as Shakespeare, Dostoyevsky, Flaubert, Camus and Melville have all written major works which identify with the genre (Weisberg 1984). Legal FASP, in keeping with the defining characteristics of the genre as a whole, relates to popular fiction, and as such belongs to a growing field of academic research interested in law and popular culture which Michael Asimow, professor of law at UCLA, describes as follows: 
The law and popular culture movement takes seriously works of popular legal culture, meaning stories about law, lawyers, or the legal system in film, television, or print. It treats these cultural artefacts as legal texts, as important in their own way as statutes, administrative rules, or judicial precedents. (2001: 1340)

Legal FASP - or legal fiction, legal thrillers, legal novels, as the genre has also been variously called - is arguably the most important FASP sub-genre not only in terms of authorship, readership and volume, but equally in terms of diversity and genre crossing, as Robinson confirms:

The sheer number of lawyer/authors dictates that the major characteristic of the genre is enormous diversity in writing styles, themes and series characters. The legal thriller is a hybrid of hybrids. [...] Just as the courtroom drama pulls in elements of every form of drama and comedy in fiction, the legal mystery also takes elements from every other mystery sub-genre - the regional mystery, the spy story, the locked room, the financial thriller, the gumshoe detective, and others. (1998: 32)

Given this diversity, some taxonomic ordering of the genre may be useful. Even though the English-speaking world obviously extends beyond the United Kingdom and the United States, a preliminary taxonomic approach to legal FASP consists in dividing the genre into a broad binary categorisation, legal FASP relevant to English ${ }^{2}$ legal culture on the one hand, and legal FASP relevant to American legal culture, on the other. Using this as a starting point, it is possible to establish five mainstream legal FASP sub-genres:

A. The lawyer novel characteristically centres round the lawyer protagonist and is often written, in classic FASP tradition, by a former or practising professional himself. John Mortimer's Rumpole of the Bailey series is an example of the English barrister protagonist, while John Grisham's different lawyer-heroes are considered to be representative of the American lawyer ethos.

B. Courtroom drama is another dominant trend in legal FASP. While, like the lawyer novel, it is essentially constructed round a lawyer protagonist, its specificity lies in that it exploits what Robin Lakoff (1990: 86) refers to as "the pyrotechnics and razzle-dazzle" of Anglo-Saxon adversarial courtroom procedure to produce drama and suspense. Erle Stanley Gardner's prolific Perry Mason series is an exemplification of the sub-genre.

C. Procedural thrillers tend to be plot-driven novels - as opposed to character-driven lawyer FASP - in which the suspense focuses less on the whodunit construct as on points of law or legal processes and procedures and their outcome. Reginald Rose's play Twelve Angry Men (1957) deals less with the guilt of the defendant per se as with the interpersonal dynamics and processes involved in the reaching of a verdict by the twelve members of a lay jury. Similarly, in John Grisham's The Rainmaker (1995), the suspense focuses on the outcome of the processes, legal and illegal, set into motion by the lawsuit initiated against a medical insurance company.

9 D. In a shift away from law towards law enforcement, we find the police procedural mystery - often subsumed into the detective thriller - which typically features a police officer, male or female, as a hero-protagonist. In keeping with the professional culture of law enforcement, police procedurals are often constructed around the idea of a team with recurrent protagonists and secondary characters. Added interest is often provided by a well-identified "geo-cultural" urban setting, such as Edinburgh for Ian Rankin's Inspector Rebus series or Oxford for Colin Dexter's Inspector Morse series. 
10 E. Forensic thrillers mark the borderline between legal and medical-anthropology FASP with a substrat professionel which leans more towards the scientific and technical aspects of forensics than law. This sub-genre is uncontestedly exemplified by two North American FASP authors, Kathy Reichs and Patricia Cornell, both forensic experts in their own right.

\section{Fictional representations of the American lawyer}

11 The fictional representation of the lawyer in popular literature has been the object of substantial academic research, especially in the United States where professionals are concerned by the increasingly negative image of what was once an esteemed profession.

\subsection{An image problem specific to American lawyers}

12 If the American legal system has its roots in English legal thinking and culture, the divergences between the two systems tend more to be the focus of attention today than the convergences - two judicial systems separated by a common legal culture, to paraphrase a well-known remark. ${ }^{3}$ One of the most perceptible areas of divergence, notably at the level of lay perceptions, concerns the question of image: American lawyers suffer from an exceedingly negative image, a phenomenon which would appear to be one of the cultural specifics of the profession in the United States since it is conspicuous by its absence with regard to both English and Continental lawyers.

One informal indicator of "the ugly American lawyer" image is the widespread prevalence of lawyer jokes. While examples abound and several websites exist entirely devoted to the subject, one particular lawyer joke gained worldwide fame through the 1993 film, Philadelphia:

"What do you say when you hear there are a thousand lawyers chained together at the bottom of the sea?"

"It's a good beginning!"

If every country, indeed every community, adopts members of another community as the target of politically incorrect jokes - the Belgians in France, the Polish in Canada, the Irish in England - the Americans seem to have adopted the lawyer as the national butt of jokes. It is not the existence of lawyer jokes which is in itself intriguing but the fact that in a country so large and diversified as the United States, lawyers should have become a negative integrator powerful enough to unite the whole nation behind the view that this is the one profession everybody loves to hate.

15 Asimow (2000) provides more formal indicators of the public's negative perceptions of American lawyers in his reporting of polling data gathered in a survey commissioned by the America Bar Association in the early 90's. The object of the survey was to assess how favourably public opinion rated lawyers with regard to other comparable professions:

Table 1. American Bar Association (ABA) Poll (1993)

\begin{tabular}{|l|l|}
\hline Teachers & $84 \%$ \\
\hline Pharmacists & $81 \%$ \\
\hline
\end{tabular}




\begin{tabular}{|l|l|}
\hline Police Officers & $79 \%$ \\
\hline Doctors & $71 \%$ \\
\hline Bankers & $56 \%$ \\
\hline Lawyers & $40 \%$ \\
\hline Stockbrokers & $28 \%$ \\
\hline Politicians & $21 \%$ \\
\hline
\end{tabular}

16 The public's low esteem for lawyers was further confirmed by a later 1999 ABA survey whose findings showed that while only $27 \%$ of the respondents expressed little or no confidence in the American judicial system as a whole, as many as $42 \%$ expressed little or no confidence in lawyers.

\subsection{Fictional images of American lawyers}

17 As might be expected, substantial research has been devoted to explaining the image problem American lawyers suffer from. Certain analysts perceive the phenomenon as necessary and "sanitary", as for example political scientist McDowell, for whom the current depiction of the American legal system in novels has gained in "authenticity" since the earlier period:

Where Gardner's Perry Mason would go only as far as complaining that the authorities were "sullen, indifferent or downright hostile" to persons accused of crime, the authors of today's legal fiction expose the manipulations of the justice system as practiced by the police, prosecutors, judges and by their lawyer-heroes as well. (2000: 78)

Understandably however, members of the legal professions do not take quite the same view and several studies have attempted to understand and analyse the phenomenon. Various explanations have been advanced ranging from the absence of formal court wear, to envy (for the large fees American lawyers reputedly command), and aggressive client "soliciting", phenomena identified as being specific to the professional culture of American lawyers and in sharp contrast with their European counterparts.

Another explanation frequently proposed is the fictional representation of American lawyers in popular literature. American lawyer FASP authors, it is argued, tend towards excessively negative portrayals of lawyers in their works of fiction and thus contribute largely to perpetrating and perpetuating negative perceptions of the profession. Creo points an accusing finger at Grisham in this respect:

[John Grisham's] protagonists are disenfranchised lawyers or law drop-outs. Greed motivates the execution of their "ends justify the means" philosophy. The villains are generally old line law firms and greedy, corrupt Corporate America. The protagonists' guillotines fall on the collective neck of the profession too. Almost every lawyer in his recent books acts unethically. [...] Not a single lawyer or judge emerges as an honorable voice for the profession or the public." (1997)

20 And yet, not all legal fiction portrays lawyers negatively as evidenced by Erle Stanley Gardner's portrayal of Perry Mason, the prototypical FASP lawyer protagonist. And a 
more analytical study of a representative sampling of American legal FASP reveals the existence of a more nuanced picture gallery of lawyer protagonists. ${ }^{4}$

\subsection{Fictional categorisations: from good to bad to evil}

21 If we consider the more popular legal FASP works published over the past half century, it is possible to group fictional lawyers, on the basis of commonly appreciated personal and professional traits, into five broad categorisations along a spectrum ranging from idealisation to demonisation.

\subsubsection{Idealisation}

Atticus Finch, the lawyer protagonist of Harper Lee's only published work of fiction, To Kill a Mockingbird (1960), occupies cult status in the fictional pantheon of decent, principled and humanistic lawyers who abide by a code of ethics applied equally to family, society and profession:

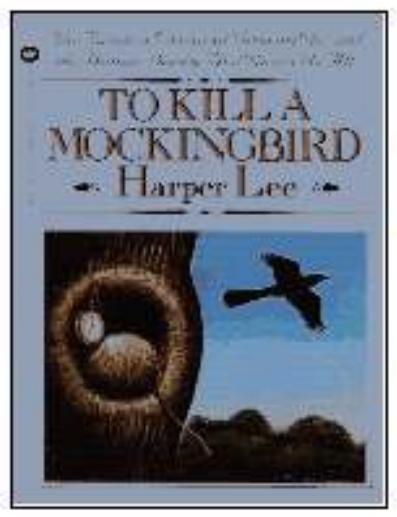

Atticus Finch lives his professionalism. He is true to his ethics and values, declining to create a dichotomy between work and personal life. The Finchs' neighbour, Miss Maudie, recognizes this and pays Atticus, and the profession, the highest compliment: "Atticus Finch is the same in his house as he is on the public streets." (Creo 1997)

Harper Lee's lawyer protagonist may be "the dream that young lawyers hope to achieve and that old lawyers regret having lost", (Strickland, 1997: 17) but he is no saintly paragon of all virtues and, like the classic flawed hero of Greek tragedy, has his doubts and moments of weakness. ${ }^{5}$ These, however, only serve to render him all the more credible and probably explain why, almost half a century later, Atticus Finch continues to be revered by law students who award him iconic status and consider him a role model of professional integrity. ${ }^{6}$ The following quotation provides an insight into this fictional lawyer's way of dealing with a conflict between personal and professional values on the one hand, and public pressure on the other:

"Well, most folks seem to think they're right and you're wrong..."

"They're certainly entitled to think that, and they're entitled to full respect for their opinions," said Atticus, "but before I can live with other folks, I've got to live with myself. The one thing that doesn't abide by majority rule is a person's conscience." (1960: 111) 


\subsubsection{Humanisation}

lawyers who fight for the right cause but, in the view that the end justifies the means, do not hesitate to bend the rules of professional ethics or even the law. The prototype of such legal FASP lawyer protagonists is, of course, Erle Stanley Gardner's Perry Mason, whose pragmatic approach embraces unorthodox investigation and trial tactics. In The Case of the Velvet Claws (1933) Perry Mason justifies his all-is-fair-in-love-and-war philosophy by explaining: "I'm a lawyer. I take people who are in trouble and I try to get them out of trouble. [...] If the District Attorney would be fair, then I could be fair too."

\subsubsection{Redemption}

In this categorisation, we find the vice-to-virtue syndrome of the bad lawyer turned good. One illustration of this evolution is a character from one of John Grisham's books, The Street Lawyer (1998) in which the hero, an archetypal greedy "big firm" lawyer, undergoes a Damascene conversion and gives up his big firm lawyer status to work for the homeless as a solo practitioner.

\subsubsection{Degeneration}

Here we have the reverse syndrome, the good lawyer sliding downhill or "degenerating" in the literal acceptance of the term as signifying a falling away from norms of excellence, declining in character and qualities. The fictional lawyer who is perhaps most illustrative of this category is once again a John Grisham lawyer protagonist, Clay Carter, a Public Defender who turns into the archetypal American ambulance-chasing, publicity-seeking, nouveau riche tort lawyer in The King of Torts (2003):

The December cover of Capitol Magazine featured Clay Carter, looking tanned and quite handsome in an Armani suit, perched on the corner of his desk in his finely appointed office. How often would the magazine have the chance at the unbelievable story of a broke young lawyer who got rich so fast? There was Clay on his patio with a dog, one he'd borrowed, and clay posing next to the jury box in an empty courtroom as if he'd been extracting huge verdicts from the bad guys, and of course, Clay washing his new Porsche. He confided that his passion was sailing, and that there was a new boat docked down in the Bahamas. (2003: 213)

\subsubsection{Demonisation}

And finally, at the very other end of the scale, we have the portrayal of the lawyer as a totally unscrupulous and unethical shark without a single personal or professional redeeming trait - the prototype for all American lawyer jokes.

One particular lawyer FASP author has carried this categorisation to the extreme limits of fictional demonisation by imagining his lawyer protagonist as the physical embodiment of the devil himself, thus turning the lawyer and the law firm into powerful metaphors for evil. The book in question is Andrew Neiderman's The Devil's Advocate (1997) in which the devil incarnates as a Manhattan lawyer called John Milton (with explicit references to Paradise Lost and Lucifer). If the chauffeur, Charon, is a metaphorical conceit, the lawyeras-a-devil is quite literal, as the hero, Kevin Lomax, explains: 
"I have good reason to believe I work for the devil or the devil's advocate. Whatever we call him, he's someone or something with supernatural powers, and he uses these powers to assist the forces of evil at work in our world." [...]

Father Vincent remained stoical, thoughtful for a moment, and then nodded. "You mean all this literally, I assume?"

"Oh yes." (Neiderman 1997: 277)

\section{Evolution of the FASP lawyer protagonist} background of racial tension in the South of the United States, both are about a white lawyer in financial straits who nevertheless agrees to defend, pro bono or almost, an indigent black man charged with a heinous crime in a capital case, the victim of which is a marginal white. And by so doing, both lawyers come up against the hostility of their fellow white citizens and expose their own families to great danger.

Besides such similarities in plot construction, both authors have chosen to portray their protagonists as anti-heroes in the non-professional spheres of their lives as the following passages - Atticus Finch as seen by his nine-year old daughter and Jake Brigance as he sees himself in the morning mirror - sympathetically but nevertheless, mercilessly underline: 
Atticus was feeble: he was nearly fifty. When Jem and I asked him why he was so old, he said he got started late, which we felt reflected on his abilities and manliness. He was much older than the parents of our school contemporaries, and there was nothing Jem or I could say about him when our classmates said, 'My father -'. [...]

Our father didn't do anything. He worked in an office, not in a drugstore. Atticus did not drive a dump-truck for the county, he was not the sheriff, he did not farm, work in a garage, or do anything that could possibly arouse the admiration of anyone. Besides that, he wore glasses. [...]

He did not do things our schoolmates' fathers did; he never went hunting, he did not play poker or fish or drink or smoke. He sat in the living-room and read.

(To Kill a Mocking Bird 1960: 95)
Jake stepped to the sink and splashed cold water on his face and hair. He switched on the light and gasped in horror at the sight in the mirror. His straight brown hair shot in all directions, and the hairline had receded at least two inches during the night. Elther that or his forehead had grown. His eyes were matted and swollen with the white stuff packed in the corners. A seam in a blanket left a bright red scar along the left side of his face. He touched, then rubbed it and wondered if it would go away. With his right hand he pushed his hair back and inspected the hairline. At thirty-two he had no gray hair. Gray hair was not a problem. The problem was pattern baldness, which Jake had richly inherited from both sides of his family. He longed for a full, thick hairline beginning an inch above his eyebrows.

(A Time to KIII 1989: 18-19)

The differences between these two la
characters in the professional spheres
with, To Kill a Mockingbird has only
whose personal and professional pro
discussion of any lesser vision of the p
In contrast, A Time to Kill is simply
varying hues of personal and profess
depiction. However, if these portray
previously discussed, the author quite
A Time to Kill does indeed feature one
in typical Grisham tradition according
students or law professors, this charact
protagonist, as befits his status as the
champions the right causes but bends
lawyers who play a role of any sign
degenerate and/or professionally crook
This comparison of two lawyer FASP
particular literary era, allows us to gaug the fictional representations of lawyers over a thirty-year span. It also serves to underline the fact that the American lawyer FASP genre today projects an unequivocally jaundiced view of the profession. This is further supported by an exhaustive study conducted by Asimow (2000) tracing the evolution of lawyer representations in cinematic legal FASP (284 films) over the last half-century:

Table 2. Representations of lawyers in cinematic legal FASP (adapted from Michael Asimow, 2000)

\begin{tabular}{|l|l|l|l|}
\hline & $\begin{array}{l}\text { Positive } \\
\%\end{array}$ & $\begin{array}{l}\text { Negative } \\
\%\end{array}$ & $\begin{array}{l}\text { Mixed } \\
\%\end{array}$ \\
\hline $1950-1959^{*}$ & 72 & 23 & 4 \\
\hline
\end{tabular}




\begin{tabular}{|l|l|l|l|}
\hline $1960-1969^{*}$ & 76 & 19 & 5 \\
\hline $1970-1979$ & 37 & 58 & 5 \\
\hline $1980-1989$ & 35 & 45 & 20 \\
\hline $1990-1999$ & 42 & 47 & 11 \\
\hline * From the 30's to the 60's, censorship blocked production of lawyer films projecting a negative image of the profession \\
\hline
\end{tabular}

We note that once censorship restrictions were abolished, positive representations plummeted and negative representations soared, stabilising at a slightly lower but nevertheless high level throughout the 80's and 90's. We also note that while positive representations do pick up somewhat during the 90 's, they only do so at the expense of mixed representations and not negative ones, which continue to climb.

One of the questions raised by such data concerns the reasons why lawyer FASP authors feel the need to paint such ugly portraits. This question is all the more intriguing as most lawyer FASP authors are, or were, practising lawyers themselves and should therefore, be aware of the dangerous ground they tread by fuelling negative perceptions of their own profession through their fictional representations, a paradox which Creo, underlines with respect to Grisham:

I suspect that Grisham, who still tries [sic] cases (e.g., a Jones Act case to a successful six figure verdict in 1996), would be mortified if any of his readers assume he practices law like his protagonists. (1997)

41 One mundane explanation to this consistently negative depiction of lawyers may simply reside in the desire to sell books by catering to genre reader expectations. These tend, on the one hand, towards strong Manichean portrayals - airport fiction, to which a substantial part of the genre belongs, does not specialise in the nuanced approach - and, on the other, look out for like-minded characterisation which reflects their own attitudes and beliefs. Negative fictional portrayals are therefore carefully cultivated to sell books, as Asimow points out with regard to films:

If lawyers are already loathed by the likely consumers of a new film, then the odds of commercial success for a film about loathsome lawyers are better than the odds on films putting down French teachers, rabbis or grandmothers. As a result, writers tend to write stories that feature negative lawyer portrayals, and producers and investors tend to select such stories from the vast array of choices available to them. (2000: 549)

Added to which is the undisputable fact that the bad, the wicked and the evil generate greater fascination than the good and saintly. As Grisham himself says (quoted in McDowell, 2000: 73), "Americans distrust the legal profession as a whole, we have an insatiable appetite for stories about crimes, criminals, trials and all sorts of juicy crooked lawyer stuff."

\section{Lawyer FASP. leader or follower of public opinion?}

In view of the undeniably negative image that surrounds American lawyers both in the real and fictional world, a recurrent question in this field of enquiry concerns the 
possible causal correlation between the two - in other words, is the negative portrayal of American lawyers in lawyer FASP the cause or the effect of public opinion? Is it a mirror of perceptions or a projector of representations that moulds those perceptions?

There is somewhat of a controversy surrounding the foundation for society's negative image of lawyers. Some opine that the reason for this unfavourable image is the fact that the public has more exposure to "real" lawyers than ever before; while others postulate that it is television, fiction writings, and movies that occasion this disheartening look. (Haddad 2000: 674)

The first school of thought (Robinson 1998; McDowell 2000) feels that fiction is a barometer of public attitudes and that the portrayal of fictional lawyers merely reflects our own ambivalence towards real lawyers, an ambivalence which is largely generated by the very nature of the profession called upon to defend not only the innocent but also the hideously guilty. Added to which is the fact that the profession is generally associated with the unhappier events of life against which the lawyer's - expensive - intervention provides no guarantee as to a satisfactory outcome. According to this line of thinking, it is therefore reality that moulds fictional representations. In which case, and in view of the increasingly venomous portrayal of fictional lawyers, we must logically subscribe to the hypothesis that real life lawyers in America today are, on the whole, as they appear in current lawyer FASP novels i.e., greedy, dishonest, unethical, etc. Such a line of reasoning is patently reductionist and borders on untenable over-simplification and stereotypical over-generalisation which deny all the decent and dedicated lawyers who never make the headlines for precisely those reasons. Trach (2003) argues in defence of "real" lawyers:

The legal profession is one that demands integrity, and most lawyers take that very seriously. The idea that lawyers are driven by greed and that successful lawyers don't do pro bono work is also false. Several examples serve to defeat this assumption. In 1999, some 170 lawyers donated their time and services to a Pro Bono program that provides free legal services to those who do not qualify for legal aid. Is this work of people who can be equated with the devil?

The other line of argument stems from what psychologists call "the cultivation effect" which concerns the influence of exposure to media on a consumer's conception of social reality. In the context of our discussion, according to cultivation effect theorists it is fiction that moulds reader perceptions and consequently, the negative image which clings to American lawyers is, to a large extent, generated by lawyer FASP, whether bestseller or blockbuster. In the same line of thinking, Creo (1997) specifically targets John Grisham in this respect: "The books of John Grisham are everywhere, littering airplanes, beaches as well as the minds of those who receive their facts, who confirm their own perceptions from fiction."

In an age of media studies, there is constant preoccupation with regard to the power of the media to influence and control minds, attitudes and behaviour. In this perspective, the defining characteristic of the FASP genre, the substrat professionnel and the special status of the FASP author - that expert, that specialist, that "insider" - contribute heavily to endowing the genre with high "truth" and "credibility" value which fudge the line between fact and fiction, between author and professional. In the context of FASP novels, these perceptions weaken and distort such essential text analysis and interpretation tools as source discount and critical distance. This is particularly relevant with reference to professional facts, phenomena and data provided by the authoritative authorprofessional whose credentials are firmly established by the persuasive dust jacket 
"blurbs" or "paratexte" which Petit (2000) identifies as one of the extrinsic defining characteristics of the FASP genre.

In view of these elements, it should come as no surprise that constant exposure to negative representations, albeit fictional, which tend to coincide with readers' own limited experience and pre-existing fragmentary and erroneous perceptions, erode the reader's critical approach to fictional representations of professionals. As such, lawyer FASP, through its consistently ugly depiction of lawyers, must certainly be recognised as instrumental in moulding readers' perceptions and thus contributing to the negative image of the profession as a whole.

However, questions of causality and correlation are not easy to determine and revolve, in many ways, around the classic issue of the chicken or the egg or the serpent biting its own tail. Public perceptions and fictional representations are caught up in what appears to be a self-perpetrating cycle in that they both feed off and fuel each other, thus generating an ever widening and unstoppable vicious circle around the antonymic processes of simultaneously both satisfying and whetting appetites.

\section{Conclusion}

There may however be one small deviant ray of hope. This optimistic note comes from the members of the cinema industry, in other words those professionals who serve as intermediaries between the author, the book and the vast cinema-going public. As such, they occupy a strategic position as exceedingly powerful modellers of perceptions, perhaps even more so than authors themselves, given the medium's far-reaching power to influence minds and shape perceptions.

In one of the many centennial/millennium surveys conducted a few years ago, the American Film Institute commissioned a survey of 1,500 leaders from the American film community (directors, actors, screen writers, critics and film historians) who were asked to nominate and rank the 50 heroes and villains whom they considered had dominated the century's cinematic history.

51 From the results of the survey, we discover that, in spite of the negative fictional portrayals of American lawyers in vogue over the past thirty years - perpetrated and perpetuated to a large extent by these very same participants - the award for the century's top cinema hero figure went surprisingly to no other than homely Atticus Finch himself, superseding such other more conventionally glamorous heroes like Indiana Jones $\left(n^{\circ} 2\right)$ and James Bond $\left(n^{\circ} 3\right)$. We also discover that Juror $n^{\circ} 8$ from the classic legal cinematic FASP Twelve Angry Men also made the list and ranked 28/50, while Erin Brockovich, another legal cinematic FASP protagonist from the eponymous film, ranked $31 / 50$.

But perhaps even more intriguing is the conspicuous absence of lawyer protagonists on the hit parade of the century's top fifty villains. The first FASP villain is to be found ranked 24 and it is Gordon Gekko, a financial FASP protagonist - a choice which marks an important paradigmatic shift in villainy from law to money...

53 The results of this last survey are of particular interest in the framework of this discussion where they may be seen as contradicting much of the data and conclusions presented. One plausible interpretation of this discrepancy may be a possible awareness of current excesses and an attempt, by those largely responsible for them, at some form 
of self-exculpation and/or damage control by preaching, if not actually practising, a more balanced view of the profession.

As a language teacher writing for a specialised review in language teaching, it is difficult to ignore the fact that a somewhat similar dilemma faces the language teacher who uses popular legal FASP as resource material. By way of conclusion therefore, we would like briefly to touch upon the didactic wisdom of exposing learners to teaching supports likely to propagate and reinforce existing negative impressions regarding the profession. This is particularly true in the case of young impressionable learners whose knowledge of the domain subject is often based on vague and even erroneous fragments of knowledge acquired randomly (Isani 2001) and who work in an autonomous self-learning environment. (Isani in press).

One of the responses to the many questions raised by this conundrum is perhaps to be found in the refocusing of the teacher's role in learning processes metamorphosed by the advent of information technology, self-learning centres and the theories behind learning to learning, learner autonomy, self-evaluation, peer evaluation, etc. In view of today's easy access to information, the teacher as a purveyor of knowledge is rapidly being outpaced and made redundant by the ubiquity and rapidity of information technology. This has led to redefining traditional teaching/learning parameters towards a more Socratic approach where the teacher's role is that of mentor, guide and facilitator. As such, the teacher's main mission today has less to do with transmitting factually correct information about the domain subject than with guiding the learner towards the acquisition of a more critical approach to received information - an objective whose ambitions extend to well beyond the language learning context.

\section{BIBLIOGRAPHY}

Asimow, Michael. 1996. "Embodiment of evil: Law firms in the movies". UCLA Law Review 48/6 1340-1392 <http:/tarlton.law.utexas.edu/lpop/etext/usf/asimow30.htm>.

Asimow, Michael. 2000. "Bad lawyers in the movies". Nova Law Review 24/2: 533-584 <http:// tarlton.law.utexas.edu/lpop/etext/nova/asimow 24.htm>.

Asimow, Michael. 2001. "When lawyers were heroes". University of San Franciso Review 30/4, 1131-1138 <http:/tarlton.law.utexas.edu/lpop/etext/usf/asimow30.htm>.

Creo, Robert A. "An essay on professionalism: The portrayal of lawyers in popular fiction" <http:/ www.rcreo.com/pg14.cfm>.

Diaz-Santos, Gilberto. 2002. "Technothrillers and English for science and technology". English for Specific Purposes 19, 221-236.

Gardner, Erle Stanley. 1933. The Case of the Velvet Claws. London: Heineman.

Grisham, John. 1992. A Time to Kill. London: Arrow Books.

Isani, Shaeda. 2001. "Calques et emprunts culturels ou le paradoxe de la culture professionnelle cible comme vecteur de perceptions erronées dans la culture professionnelle source - le cinéma 
et les professions juridiques". Culture \& communication en milieu professionnel interculturel, coll. CERELC, Université Stendhal Grenoble 3, 105-120.

Isani, Shaeda. 2004. "The FASP and the Genres within the genres”. In Petit, Michel \& Shaeda Isani. Aspects de la fiction à substrat professionnel. Bordeaux : Université Victor Segalen Bordeaux 2, collection Travaux 2025, 25-35.

Isani, Shaeda. (In press). "Revisiting cinematic FASP and English for legal purposes in a selflearning environment". Les Cahiers de l'APLIUT.

Haddad, Tonja. 2000. "Silver tongues on the silver screen: Legal ethics in the movies". Nova Law Review 24/2, 673-700 <http://tarlton.law.utexas.edu/lpop /etext/nova/haddad24.htm>.

Lakoff, Robin. 1990. Talking Power: The Politics of Language, 85-106. USA: Basic Books.

Lee, Harper. 1960. To Kill a Mocking Bird. Oxford: Heineman Educational Publishers.

McDowell, James L. 2000. "From Perry Mason to Primary Colours: Using fiction to understand legal and political systems". Legal Studies Forum 24/1, 73-97 <http://tarlton.law.utexas.edu/lpop/etext/ forum/mcdowell.htm>.

Neiderman, Andrew. 1990. The Devil's Advocate. London: Random Century Group.

Owens, John B. 2001. "Grisham's legal tales: A moral compass for the young lawyer". UCLA Law Review 48/6, 1431-1442 <http://tarlton.law.utexas.edu/lpop/etext/ucla/owens48.htm>.

Petit, Michel. 1999. "La fiction à substrat professionnel: une autre voie d'accès à l'anglais de spécialité”. ASp, la revue du GERAS 23-26, 57-81.

Petit, Michel. 2000. “Le paratexte dans la fiction à substrat professionnel”. Bulletin de la société de stylistique anglaise 21, Texte et Paratexte, Actes du Colloque de Nanterre 4-5 juin 1999, 173-195.

Robinson, Marlyn. 1998. "From Collins to Grisham: A brief history of the legal thriller". Legal Studies Forum 21, Tarlton Law Library - Law in Popular Culture Collection <hhtp:// www.law.utexas.edu/pop/legstud.htm>.

Strickland, Rennard. 1997. "The Cinematic lawyer: The magic mirror and the silver screen". Oklahoma City University Law Review 22/1, 13-23 <http://tarlton.law.utexas.edu/lpop/etext/okla/ strickland22.htm>.

Trach, Lisa. 2003. "Does Pop Culture libel law and lawyers?". The On-Line Journal of Law \& Popular Culture <http://www.usfca.edu/pj/libel_trach.htm>.

Weisberg, Richard H. 1984. The Failure of the Word - The Protagonist as Lawyer in Modern Fiction. Michigan: Yale University.

\section{NOTES}

1. As explained in a previous publication (Isani 2004: 25), after much debate as to whether or not to translate FASP into English, it was decided that, in the tradition of other literary genres which have kept their original French appellations in English - policier, roman noir, roman à clé transposition would be preferable to translation and the term FASP would be adopted for English as well.

2. English - as opposed to American - would also be extended to include Scottish legal FASP in spite of the fact that divergences in the two legal systems make the Scottish legal FASP an interesting sub-genre in its own right.

3. G. B. Shaw, "England and America are two countries separated by a common language." 
4. For reasons of brevity, the main focus of this discussion will be on legal FASP books, leaving aside, for the time being, the equally interesting domain of legal FASP cinema and television.

5. A number of critics have questioned the moral probity of Atticus Finch's tacit acceptance that Boo Radley's killing of Ewell while attacking Scout, his 9-year old daughter, should be covered up. 6. However, in a 2004 Princeton Review survey, nearly 50\% of the student respondents answered that they would choose Kevin Lomax, the unprincipled lawyer in The Devil's Advocate as a defence lawyer. Owens (2001: 1431) poses the same question when he asks which lawyer a client would prefer, the noble Atticus Finch or the "unethical" street lawyer of Grisham's legal tales?

7. One of the precepts of the famous Hays Code was that "law, natural, divine or human, shall not be ridiculed, nor shall sympathy be created for its violation." Moreover, "special care" was to be exercised with respect to "titles or scenes having to do with law enforcement or law-enforcing officers." (Asimow, 2000: 570)

\section{ABSTRACTS}

The aim of this article is to analyse the fictional representations of lawyers in American legal fiction or FASP, fiction à substrat professionnel. After a brief introduction to the legal FASP subgenre, the article proposes a taxonomy of different lawyer representations and discusses the evolution of the American lawyer's portrayal in popular fiction over the last half-century. To conclude, it attempts to address the question of whether lawyer FASP is a mirror or modeller of public opinion and the current negative image of the profession.

L'objectif de cet article est d'analyser le portrait de l'avocat américain tel qu'il apparaît à travers la FASP (fiction à substrat professionnel) juridique. Après une brève introduction aux spécificités du sous-genre de la FASP juridique, l'article propose une taxonomie de représentations fictionnelles d'avocats américains et trace son évolution au cours du dernier demi-siècle. En conclusion, il pose la question de savoir dans quelle mesure la FASP juridique serait à l'origine de l'image négative dont souffre la profession aux États-Unis ou si, inversement, ce sont les perceptions qui influent sur les représentations fictionnelles.

\section{INDEX}

Keywords: cinematic legal FASP, fictional representation of lawyers, lawyer FASP, legal FASP

Mots-clés: FASP juridique, FASP juridique cinématographique, avocat (américain), Grisham (John), Lee (Harper), représentation fictionnelle de l'avocat américain

\section{AUTHOR}

\section{SHAEDA ISANI}

Shaeda Isani est Professeur des universités à l'Université Stendhal Grenoble 3 où elle enseigne au Département d'anglais appliqué, LEA. Ses enseignements et sa recherche portent sur la 
didactique des langues et cultures de spécialité (droit et économie) et l'évaluation en langue. shaeda.isani@u-grenoble3.fr 